\title{
Implementasi Media Tajwid Putar dalam Pembelajaran Ilmu Tajwid
}

\author{
Yesi Fadlilah \\ IAIN Jember \\ yesifadlillah23@gmail.com

\section{Zainal Abidin \\ IAIN Jember \\ za1981nawawi@gmail.com}

\begin{tabular}{|c|c|}
\hline Submission & ABSTRACT \\
\hline Track: & Studying Tajwid (science of reciting the Koran) is the fardlu \\
\hline Received: & kifäyah, but practicing it in reciting the Koran is fardlu 'ain, so \\
\hline 6 Agustud 2020 & $\begin{array}{l}\text { Tajwid has been taught to Muslim children since they learned to } \\
\text { recite the Koran. However, it has been considered to be very }\end{array}$ \\
\hline Final Revision: & demanding and problematic. The conventional methods used tend \\
\hline 1 Sepetember 2020 & $\begin{array}{l}\text { to be uninteresting and boring. For that reason, a learning media } \\
\text { that makes teachers and students is in an interactive, effective and }\end{array}$ \\
\hline Available online: & $\begin{array}{l}\text { joyful learning process is needed. One of them is Tajwid Putar, a } \\
\text { media created by Jeni Agustina Suyanto, a teacher of MAN } 1\end{array}$ \\
\hline 25 September 2020 & Lubuklinggau, South Sumatra. According to her, TPQ Ar-Risalah \\
\hline Corresponding & $\begin{array}{l}\text { is the only educational institution in East Java that used Tajwid } \\
\text { Putar. The objectives of this study were to describe the Tajwid }\end{array}$ \\
\hline Author: & learning process by implementing Tajwid Putar, the students' \\
\hline Name \& E-mail Address & $\begin{array}{l}\text { interest in learning in Tajwid using Tajwid Putar, and the learning } \\
\text { achievement in Tajwid using Tajwid Putar. This study used a }\end{array}$ \\
\hline Yesi Fadlilah & qualitative approach. The data was collected by interview, \\
\hline yesifadlillah23@gmail.com & interactive model of Miles and Huberman. The result suggested \\
\hline Zainal Abidin & $\begin{array}{l}\text { that the learning process of Tajwid which employed the Tajwid } \\
\text { Putar has been effectively made students to be more active, }\end{array}$ \\
\hline za1981nawawi@gmail.com & $\begin{array}{l}\text { interactive and festive, so that they quickly understood Tajwid and } \\
\text { was able to recite the Koran well. Students' enthusiasm was } \\
\text { increased in learning Tajwid compared to the use of conventional } \\
\text { methods. The students' learning achievement was also shown to be } \\
\text { increased, which could be measured by the score of the test } \\
\text { contained within the student report book. }\end{array}$ \\
\hline
\end{tabular}

Keywords: ilmu tajwid, media tajwid putar, taman pendidikan Alquran

\section{PENDAHULUAN}

Waktu terbaik untuk mulai belajar Alquran adalah usia lima sampai enam tahun. Pada usia ini anak sedang berada pada masa keemasan. Kepekaan terhadap rangsangan atau stimulus baik internal dan eksternal mulai dialami oleh anak.. Masa ini juga merupakan masa terbaik untuk melekatkkan pondasi untuk pengembangan kemampuan kognitif, bahasa, gerak-motorik, dan sosial-emosional anak (Sujiono, 2013: 2).

Problematika yang dihadapi oleh tenga pendidikan atau guru, berkaitan dengan pengajaran al-Qur'an dengan carra proses belajar mengajar yang efektif, efisien dan menyenangkan. Sejauh observasi peneliti pada Taman Pendidikan Alquran (TPQ) di Kecamatan Ajung Kabupaten Jember, guru 
atau tenaga pendidik dalam proses belajar mengajar hanya memanfaatkan buku dan papan tulis, sehingga kegiatan pembelajaran tampak monoton dan membosankan. Anakanak (selanjutnya disebut santri) tampak tidak antusias mempelajari ilmu tajwid. Hal itu berpotensi pada rendahnya pemahaman santri terhadap apa yang disampaikan oleh ustadz/ustadzah.

Berbeda dengan TPQ-TPQ lain, TPQ Ar-Risalah yang terletak di Desa Klompangan Kecamatan Ajung Kabupaten Jember memakai media pembejalaran ilmu tajwid yang interaktif, efektif dan menyenangkan yang disebut dengan media tajwid putar. Media terbuat dari karton berbentuk lingkaran yang berisi hukum tajwid nun sukun dan tanwin serta hukum mim sukun. Penggunaan media tersebut tergolong sangat mudah, dengan memutar tanda tunjuk dengan simbol tangan ke arah bertemunya huruf maka akan muncul lubang hukum tajwidnya.

Media tajwid putar diciptakan oleh Jeni Agustina Suyanto, seorang guru Madrasah Aliyah Negeri (MAN) 1 Lubuklinggau, Sumatera Selatan. Media ini telah mengantarkan Agustina menjadi Juara I Guru Kreatif Inovatif Tingkat Nasional Kementerian Agama Republik Indonesia Tahun 2010 (www.nu.or.id). Media ini dapat digunakan sebagai alat peraga pada pembelajaran ilmu tajwid, terutama pada TPQ/TPA, SD/MI, SMP/MTs, atau sederajat.

Menurut Tri Indah Safira, salah satu ustadzah di TPQ Ar-Risalah, media ini cocok digunakan oleh santri yang masih dalam fase usia bermain. Penggunaan media ini bersifat bermain sambil belajar sehingga dapat menjadi daya tarik santri untuk mempraktikkannya bahkan dapat membawa pengaruh psikologis terhadap santri. Dengan demikian, penggunaan media ini membantu santri lebih mudah untuk memahami ilmu tajwid.

Kajian-kajian tentang media pembelajaran ilmu tajwid memang banyak dilakukan. Lidinillah (2014), Mildayanti et.al. (2016), Askuri et.al. (2017), Kharisma et.al. (2018, Fajri (2018), serta Eiva dan Putra (2020) mengkaji penggunaan aplikasi adroid dalam pembelajaran ilmu tajwid. Media ini tentu saja high cost dan kurang cocok bagi anak-anak kampung yang jarang memiliki smart phone. Zulkarnaen et.al. (2019) melakukan research and development tentang magic disc dalam pembelajaran ilmu tajwid. Hanya saja, subyeknya adalah siswa Madrasah Tsanawiyah (MTs) yang berbeda dengan anakanak TPQ secara intelektual dan emosial.

Sementara itu, Zain (2017) mengkaji penggunaan metode drill dalam pembelajaran tajwid pada madrasah dininiyah. Metode ini menekankan pada latihan berulag-ulang sehingga santri berpotensi untuk bosan. Adapun tema kajian yang relatif mirip dengan kajian ini adalah hasil peneltiian Witono (2014) yang berjudul: Penggunaan Media Ular Tangga untuk Meningkatkan Prestasi Tajwid Siswa di TPQ Mabadiul Ibsan Desa Karangdoro Kecamatan Tengalsari Kabupaten Banyuwangi. 
Kendati sama-sama memakai media yang efisien dan menenyangkan, serta lokusnya sama-sama TPQ, jenis media yang digunakan berbeda. Winoto mengkaji media ular tangga, sedangkan penulis mengkaji media tajwid putar.

Tema kajian yang mirip dengan kajian ini adalah skripsi Rhamdanasari (2013) yang berjudul: "Efektivitas Penggunaan Media Tajwid Putar terhadap Hasil Belajar dalam Pembelajaran PAI (Studi Kasus Eksperimen pada Sub Pokok Bahasan Hukum Bacaan Nun/Tanwin dan Mim Mati di SMP Negeri 3 Lembang Tabun Ajaran 2012/2013)”. Deskripsi penelitian Rhamdanasari menyimpulkan bahwa terdapat perbedaan signifikan pada hasil ternormalisasi kemampuan tingkat pemahaman pada hukum bacaan "nun mati/tanwin" dan "mim mati", antara siswa yang melakukan pembelajaran dengan media tajwid putar dengan siswa yang tidak menggunakan media tajwid putar.

Kendati sama-sama mengkaji media tajwid putar, terdapat perbedaan antara kajian Rhamdanasari denga kajian ini. Subyek kajian Rhamdanasari adalah siswa lembaga pendidikan formal jenjang SMP serta menggunakan pendekatan kuantitatif dengan metode kuasi eksperimen. Di lain pihak, subyek kajian ini adalah anak-anak pada lembaga pendidikan nornformal TPQ dan menggunakan pendekatan kualitatif jenis studi kasus.

Dari uraian di atas, kajian ini berusaha mengisi ruang kosong yang belum dikaji oleh peneliti-peneliti sebelumnya. Tujuan kajian ini adalah untuk mendeskripsikan proses pembelajaran ilmu tajwid dengan media tajwid putar, mendeskripsikan minat belajar santri dalam pembelajaran ilmu tajwid dengan media tajwid putar, dan mendeskripsikan prestasi belajar santri dalam pembelajaran ilmu tajwid dengan media tajwid putar di TPQ Ar-Risalah Klompangan Ajung Jember.

\section{METODE}

Kajian ini menggunakan pendekatan kualitatif dalam rangka memahami fenomena tentang implementasi media tajwid putar di TPQ Ar-Risalah. Subyek kajian dipilih secara purposif (Sugiyono, 2010: 52) dengan pertimbangan bahwa mereka adalah narasumber yang dapat memberikan informasi dan data sesuai fokus kajian, yang terdiri atas: kepala, para ustads/ustadzah, dan beberapa santri TPQ Ar-Risalah.

Data-data dalam kajian ini dikumpulkan menggunakan teknik observasi partisipan, wawancara semiterstruktur dan dokumen. Observasi partisipan dilakukan dengan cara melibatkan diri dalam kegiatan pembelajaran ilmu tajwid di TPQ Ar-Risalah sehingga dapat menangkap dan merasakan apa yang terjadi selama pembelajaran berlangsung.

Wawancara semi terstruktur dipilih untuk memastikan bahwa peneliti mampu menggali informasi selengkap-lengkapnya sesuai fokus kajian yang disusun dalam sebuah pedoman wawancara. Pedoman itu dijadikan panduan untuk mewawancarai subyek penelitian yang dipilih secara purposif tadi. Agar datanya terekam dengan baik, maka peneliti memakai alat perekam yang ada di 
smart phone. Hasil rekaman itu kemudian ditranskrip secara seksama menjadi transkrip wawancara.

Adapun teknik dokumen digunakan untuk mendukung data-data yang diperoleh melalui observasi dan wawancara. Selain dokumen yang sesuai fokus kajian, peneliti juga mengumpulkan dokumen yang berkaitan dengan visi, misi dan tujuan lembaga, data ustadz/ustadzah, data santri, dan struktur organisasi TPQ Ar-Risalah.

Penggunakaan observasi partisipan, wawancara, dan dokumen itu sengaja dilakukan dalam rangka triangulasi teknik, sehingga data yang diperoleh melalui observasi dapat dicek silang dengan data yang diperoleh melalui wawancara dan dokumen. Demikian juga sebaliknya. Selain triangulasi teknik, kredibilitas data juga dicek dengan triangulasi sumber. Artinya, peneliti mengajukan pertanyaan yang sama kepada beberapa narasumber yang berbeda.

Data-data yang dipandang kredibel itu kemudian dianalisis menggunakan model interaktif Miles dan Huberman (1994) yang meliputi: reduksi data, penyajian data, dan simpulan. Peneliti sengaja tidak memakai istilah kondensasi karena istilah itu tidak digunakan oleh Miles dan Huberman hingga keduanya meninggal dunia secara berturutturut pada tahun 1996 dan 2001. Istilah kondenasi baru muncul pada buku yang diadaptasi oleh Saldana yang terbit pada tahun 2014.

\section{HASIL \& PEMBAHASAN}

Proses Pembelajaran Ilmu Tajwid dengan Media Tajwid Putar

Dalam pembelajaran ilmu tajwid, TPQ Ar-Risalah menggunakan kitab Hidayāt alSibyān dan buku Pedoman Ilmu Tajwid yang disusun sendiri oleh lembaga. Sebelum memperoleh media tajwid putar, para guru menggunakan metode ceramah dan hafalan dengan media papan dan buku tulis. Menurut penuturan para ustadz dan ustadzah, santri tampak bosan dan tidak cepat memahami materi yang disampaikan oleh mereka.

Pada saat mendengar dan kemudian memiliki media tajwid putar, TPQ Ar-Risalah tidak langsung menerapkannya sebagai media utama. Mula-mula media tajwid putar ini diuji coba selama dua bulan pada akhir tahun 2016. Hasilnya ternyata sesuai dengan keinginan dan mendukung pembelajaran ilmu tajwid. Berdasarkan hasil uji coba itulah, TPQ ArRisalah memutuskan menerapkannya sejak Januari 2017 pada jenjang Marhalah, jenjang menengah pada TPQ itu.

Sebagai gambaran, media yang termasuk dalam kategori media cetakan ini dibuat dari karton yang berbentuk lingkaran yang berdiameter $20 \mathrm{~cm}$ dan dilapisi lingkaran $18 \mathrm{~cm}$ dengan dua sisi. Sisi pertama berwarna biru berisi hukum tajwid nun mati dan tanwin (lihat Gambar 1), sedangkan di sisi lain berwarna merah berisi hukum mim sukun (lihat Gambar 1). 


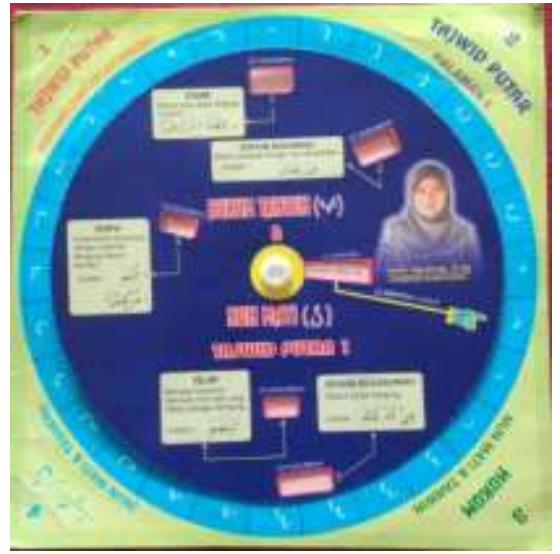

Gambar 1.

Media Tajwid Putar untuk Hukum Nun Mati dan Tanwin

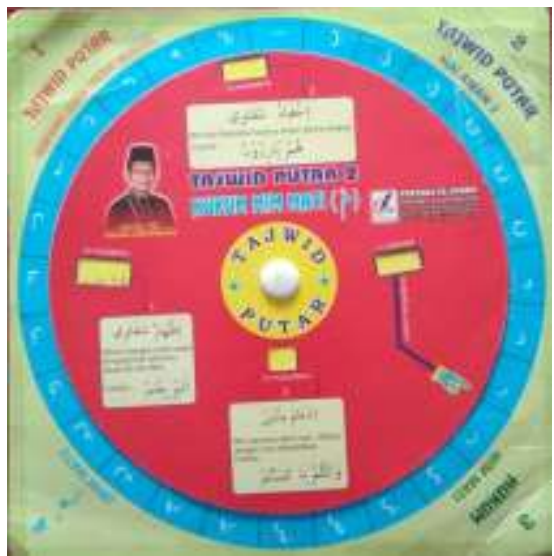

Gambar 2.

Media Tajwid Putar untuk Hukum Mim Mati

Karton yang berbentuk lingkaran berdiameter $20 \mathrm{~cm}$ terlebih dahulu disusun 28 huruf hijaiyah untuk sisi yang paling luar dan hukum nun mati atau tanwin, yaitu: "id₹̧har, ikhfa', iqlab, idgham bighunnah dan idgham bilagunnab" sesuai dengan 28 kolom dan untuk bagian muka kedua hukum mim mati, yaitu: "ikhfa' syafawi, idzhar syafawi dan idgham mitslain”. Bahan dilengkapi karton lapisan kedua berdiameter $18 \mathrm{~cm}$, diberi tanda tunjuk ke salah satu huruf hijaiyah yang berhubungan dengan lubang yang menginformasikan hukum tajwid, cara membaca dan contohnya. Keempat lapisan lingkaran disatukan dan sebagai pusatnya dipasang kancing baju dua sisi yang menyatukan keempat lapisan, sehingga karton ini dapat diputar sesuai tanda tunjuk ke huruf hijaiyah dengan hukum nun mati atau tanwin maka akan mendapat hukum tajwidnya. Begitupun juga dengan muka kedua yaitu hukum mim sukun.

Tajwid putar ini dibuat menarik dengan warna yang terang dan bentuk yang simpel dengan ukuran yang praktis, sehingga bisa dibawa dengan mudah. Adapun cara penggunaan permainan media tajwid putar, sebagaimana diperagakan sendiri oleh pencipta media ini, Jeni Agustina Suyanto, di laman YouTube berjudul Tajwid Putar dan Caranya adalah sebagai berikut:

1. lihat lubang satu jika ada,

2. lihat arah jari telunjuk bertemu huruf,

3. lihat lubang hukumnya,

4. lihat contoh dan keterangan pada kolom penjelasan hukumnya,

5. kemudian kembangkan contoh-contoh yang ada dengan melihat materi pada buku Tajwid.

Dari observasi peneliti, ustadzah di TPQ Ar-Risalah menirukan cara yang diajarkan di YouTube itu. Sebelum dia menerangkan perihal bab nun sukun atau tanwin dan bab mim sukun, dia mengenalkan terlebih dahulu tentang hukum nun sukun, pengertian dari masing-masing hukum bacaan serta menyiapkan beberapa contoh bacaan. Cara penggunaan media tajwid putar, ustadzah 
memberikan contoh bacaan kemudian santri mendengarkan sembari melihat contoh bacaan yang ditulis di papan tulis, kemudian santri mulai memutar-mutarkan medianya pertama, lihat lubang satu jika ada, kedua lihat arah jari telunjuk bertemu huruf hijaiyah berupa apa, ketiga lihat lubangnya menunjukkan hukum bacaan apa, keempat lihat contoh dan keterangan pada kolom penjelasan hukumnya.

Fina Nuri Mawaddah, salah satu ustadzah TPQ Ar-Risalah, menyatakan: "Pemilihan media ini dirasa sangat penting, baik dan efisien karena pada materi tajwid bagi seorang pemula dirasa sangat enak. Selain itu, model medianya juga menarik di mana santri bisa bermain sambil belajar."

Pernyataan Mawaddah sesuai dengan realitas di TPQ Ar-Risalah. Kegiatan belajar ilmu tajwid tidak membosankan. Santri yang rata-tara berusia 8-9 tahun tampak senang menyimak, berinteraksi, dan yang paling penting bersemangat untuk mempraktikkan media itu. Suasana belajar yang interaktif yang dikemas dalam sebuah permainan menyenangkan membuat santri menyukai pelajaran ilmu tajwid. Karena menyukai, maka mereka cepat bukan hanya menghafal macammacam hukum bacaan tetapi juga mampu mempraktikkannya dengan baik dalam membaca Alquran.

Temuan ini selaras dengan pandangan Suryadi (2007) bahwa belajar sambil bermain memiliki banyak manfaat di antaranya: (1) menghilangkan kejenuhan yang menghambat, (2) menghilangkan stres dalam belajar, (3) mengajak peserta didik terlibat penuh, (4) meningkatkan proses belajar membangun kreativitas diri, (5) mencapai tujuan dengan ketidaksadaran, (6) meraih makna belajar melalui pengalaman, dan (7) memfokuskan siswa sebagai subjek pendidikan.

Temuan ini juga sejalan dengan pandangan Mujib dan Rahmawati (2013) bahwa permainan edukatif memiliki unsur mendidik yang diperoleh dari sesuatu yang ada dan melekat serta menjadi bagian dari permainan itu sendiri. Selain itu, permainan juga memberi rangsangan atau respons positif terhadap indra pemainnya. Indra yang dimaksud antara lain pendengaran, penglihatan, suara (berkomunikasi), menulis, daya pikir, keseimbangan kognitif, motorik (keseimbangan gerak, daya tahan, kekuatan, keterampilan, dan ketangkasan), afeksi, serta kekayaan sosial dan spritual. Keseimbangan indra inilah yang direncanakan agar mempengaruhi jasmani, nalar, imajinasi, watak dan karakter, sampai tujuan pendewasaan diri.

Temuan ini sekaligus memperkuat teori yang dikemukakan oleh Hamalik (2014: 78) dalam bukunya yang berjudul Media Pendidikan. Menurutnya, ada sejumlah manfaat yang diperoleh dari menggunakan media pembelajaran dalam mengajar. Pertama, bahan pelajaran akan lebih jelas maknanya, sehingga dapat lebih dipahami oleh peserta didik dan memungkinkan peserta didik untuk menguasai tujuan pengajaran yang lebih baik. Kedua, metode mengajar akan lebih bervariasi, tidak semata-mata komunikasi verbal melalui penuturan kata-kata oleh guru, sehingga peserta didik tidak bosan dan guru tidak 
kehabisan tenaga dalam memberikan materi pelajaran. Ketiga, peserta didik lebih banyak melakukan kegiatan belajar, sebab tidak hanya mendengarkan keterangan guru, tetapi juga melakukan aktivitas lain seperti mengamati, melakukan, mendemonstrasikan dan lain-lain. Keempat, pengajaran akan lebih menarik perhatian peserta didik sehingga dapat menumbuhkan motivasi belajar.

\section{Minat Belajar Santri dalam Pembelajaran Ilmu Tajwid dengan Media Tajwid Putar}

Masruhin, salah satu ustadz di TPQ Ar-Risalah menyampaikan bahwa sejak lembaga ini menerapkan media tajwid putar, ada varian baru dalam melakukan kegiatan pembelajaran. Dia menuturkan,

"Media ini kan juga tergolong media edukatif, di mana media yang digunakan itu ada unsur bermain sambil belajarnya. Ketika saya meminjam untuk saya bawa pulang dan saya beritahukan ke anak-anak di langgar (mushalla) di rumah, mereka pun juga merespon demikian. Maksudnya mereka juga antusias dan merasa senang, sehingga motivasi mereka untuk belajar ilmu tajwid itu meningkat."

Hal serupa dikemukakan oleh Fina Nuri Mawaddah:

"Kalau menurut saya, semenjak saya menerapkan media ini kepada santri TPQ ArRisalah khususnya di tingkat marhalah kelas satu dan dua respons mereka alhamdulillah sangat antusias sekali. Minat belajar mereka akan pelajaran ilmu tajwid itu meningkat. Ini terlihat dari nilai-nilai ulangan yang setiap bulan sekali saya laksanakan. Mereka merasa kalau belajarnya itu tidak menimbulkan rasa jenuh atapun menimbulkan kebosanan, melainkan ada unsur bermain-mainnya. Soalnya kan jarang-jarang toh sekolahan nonformal yang menggunakan media seasik ini. Bagi kalangan anak-anak tho ya maksud saya he he he. Santri di sini juga merasakan kegembiraan tersendiri, Mbak. Soalnya media ini kan cara mainkannya dengan cara diputar- putar. Nah, bermula dari hal tersebut jadi anak-anak senang, Mbak."

Apa yang disampaikan oleh dua guru di atas terkonfirmasi oleh pengakuan santri. Namanya Irsya Syafira. "Saya senang Bu pakai tajwid putar ini. Saya lebih mudah dalam memahami hukum bacaan nun sukun dan mim sukun. Ndak hanya saya sib $\mathrm{Bu}$. Temanteman juga sama-sama senang," ungkapnya sambil tersenyum polos.

Ungkapan Syafira diamini oleh Masfufah, ustadzah yang menjadi wali kelas Jilid I, yang tingkatnya di bawah jenjang Marbalah. Dia mengatakan:

"Awale kulo niki geh biasa nanggapi media niku (Jawa: awalnya saya sendiri biasa saja dalam merespons adanya media [tajwid putar] itu). Kali pertama Ibu melihat dan menggunakan media ini tepatnya awal tahun 2017 Ibu mengira media apa itu, setelah diajari oleh ustdzah Marbalab akhirnya Ibu pun juga senang. Ibu merasa kalau media ini sangat membantu sekali. Sampai-sampai anak Ibu yang masih duduk di tingkat jilid Ibu belikan, guna untuk memahami materi tajwid sedari dini. Soalnya kenapa? Hukum mempelajari ilmu tajwid itu memang wajib kifayah to lab niku penting oug mbk. Maos Quran niku lo kedah sesuai kalian kaidab lan bukume ugi bukume kan geh wajib ngain to (Jawa: hukum mempelajari ilmu tajwid itu wajib kifayah, juga penting kan, Mbak. Untuk membaca Alquran pun itu juga harus sesuai dengan kaidah-kaidah). Lagi pula materi yang tertera itu merupakan materi dasar yakni tentang hukum nun mati dan tanwin serta hukum mim sukun."

Paparan di atas menunjukkan bahwa media tajwid putar itu dapat meningkatkan antusisme santri dan memacu minat belajar ilmu tajwid. Bagi santri, media tersebut merupakan media yang unik, pemakaiannya mudah, dapat dibawa kemana-kemana, efisien 
serta dapat dipelajari sendiri di rumah masingmasing. Hal ini selaras dengan teori Slameto (2010) bahwa minat dapat diukur dengan empat indikator, yaitu: ketertarikan untuk belajar, perhatian dalam belajar, motivasi belajar.

Minat mempunyai pengaruh yang sangat besar. Pasalnya, dengan minat itu maka semangat belajar bagi santri akan meningkat dan sekaligus berpengaruh terhadap prestasi belajarnya. Oleh karena itu, santri yang tidak memiliki minat belajar terhadap mata pelajaran yang diajarkan, maka santri tidak akan belajar dengan sebaik-baiknya lantaran merasa bosan dan jenuh.

Santri TPQ AR-Risalah tertarik untuk belajar ilmu tajwid karena mereka menyenangi materi itu dan tidak ada perasaan terpaksa atau tertekan untuk mempelajarinya. Santri tertarik untuk melibatkan diri dalam kegiatan yang didesain guru secara baik dengan menggunakan media yang unik dan menyenangkan. Hal inilah yang membuat santri berkonstrasi dalam permainan edukatif itu dan mengesampikan hal-hal lainnya.

Degeng sebagaimana dikutip oleh Rusydiyah (2013: 11), pakar pendidikan dari UIN Sunan Amplel Surabaya, mengemukakan bebera fungsi media, antara lain: (1) menghindari terjadinya verbalisme, (2) membangkitkan minat, (3) menarik perhatian peserta didik, (4) mengatasi keterbatasan ruang, waktu dan ukuran, (5) mengaktifkan peserta didik dalam kegiatan belajar, dan (6) mengefektifkan pemberian rangsangan untuk belajar. Begitu pentingnya media, Rusydiyah
(2013: 10) sampai pada pernyataan, "Tanpa adanya media, maka pembelajaran tidak dapat berlangsung."

Temuan ini memperkuat pandangan Rusyam et.al. (1994: 24) bahwa minat yang tinggi akan mendorong peserta didik untuk belajar lebih baik dari pada belajar tanpa minat. Minat akan timbul apabila peserta didik tertarik akan sesuatu karena merasa sesuai dengan kebutuhan atau merasa bahwa sesuatu yang akan dipelajari dirasakan bermakna bagi dirinya.

\section{Prestasi Belajar Santri dalam Pembelajaran Ilmu Tajwid dengan Media Tajwid Putar}

Prestasi belajar santri dapat dilihat dari nilai rapor dan nilai ulangan yang setiap sebulan sekali diadakan oleh wali kelas TPQ Ar-Risalah. Berdasarkan nilai rapor, prestasi belajar mengalami peningkatan, dari semula rata-rata 67,6 menjadi 82. Artinya, penggunaan media tajwid putar secara kuantitatif berhasil meningkatkan prestasi belajar santri sebanyak 15 digit dibanding pada saat memakai media konvensional (buku ajar, kitab, dan papan tulis.

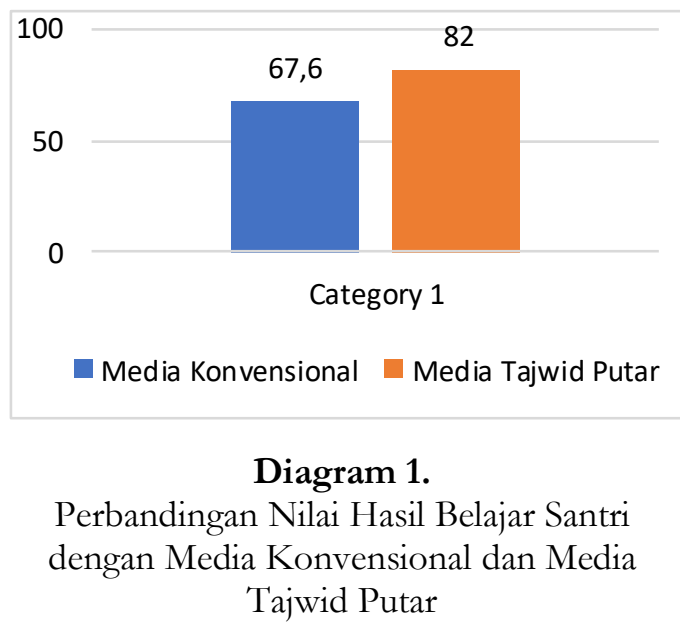


Terkait prestasi santri TPQ Ar-

Risalah, Fina Nuri Mawaddah menjelaskan:

"Semenjak pemakaian media ini, prestasi santri TPQ sini meningkat. (Ini) terlihat dari nilai ulangan yang biasa saya lakukan setiap sebulan sekali. Selain itu Mbak bisa lihat di rapor mereka. Pengisisn rapor dilakukan ketika kita sudah melaksanakan munaqasah (tes) yang diselenggarakan setiap empat bulan sekali. Penilaian yang dicantumkan dalam rapor adalah suatu cara yang dilakukan oleh ustadz-ustdzah dalam bentuk tertulis maupun tidak tertulis yang mana dari penilaian tersebut guru bisa mengetahui kemampuan santri dan menjadi bahan perbaikan kebelakangnya untuk ustadzah dan santri.”

Prestasi belajar merupakan hal yang tidak dapat dipisahkan dari kegiatan belajar, karena kegiatan belajar merupakan proses, sedangkan prestasi merupakan hasil dari proses itu. Hasil belajar ditunjukkan dengan adanya perubahan tingkah laku seseorang setelah melakukan pengalaman belajar, yaitu dari tidak tahu menjadi tahu (Sudjana dan Rivai: 2010: 22).

Menurut Muhibbin Syah (2001: 144), secara umum faktor-faktor yang mempengaruhi prestasi belajar siswa dapat dibedakan menjadi tiga macam. Pertama, faktor internal, yaitu faktor yang berasal dari dalam diri siswa. Faktor ini meliputi dua aspek yaitu: aspek fisiologis (sempurna atau tidak sempurnanya jasmani) dan aspek psikologis (seperti: intelegensi, motivasi, bakat, sikap, minat). Kedua, faktor eksternal, yaitu faktor yang ada di luar siswa. Faktor tersebut meliputi lingkungan keluarga, lingkungan sekolah dan lingkungan masyarakat. Ketiga, faktor pendekatan belajar. Tercapainya hasil belajar yang baik dipengaruhi oleh aktivitas siswa dalam belajar. Pendekatan belajar atau strategi yang digunakan untuk menunjang kegiatan sangat memengaruhi hasil belajar siswa.

Prestasi belajar memang memiliki posisi penting dalam pendidikan dengan lima alasan utama. Pertama, prestasi belajar merupakan indikator kualitas dan kuantitas materi pelajaran yang telah dikuasai peserta didik. Kedua, prestasi belajar menjadi lambang hasrat ingin tahu peserta didik. Ketiga, prestasi belajar merupakan salah satu bahan utama untuk berinovasi dan pendorong bagi peningkatan ilmu pengetahuan dan teknologi, sekaligus berperan sebagai umpan balik bagi peningkatan mutu pendidikan. Keempat, prestasi belajar merupakan indikator produktivitas institusi pendidikan dan salah satu prediktor keberhasilan peserta didik ketika hidup di masyarakat. Kelima, prestasi belajar menjadi salah satu indikator daya serap peserta didik, dan ini merupakan fokus dari semua kegiatan lembaga pendidik (Arifin, 2012: 12).

Itulah alasannya mengapa semua pendidik, termasuk ustadz/ustadzah TPQ ArRisalah, menginginkan adanya perubahan pengetahuan, sikap, dan perilaku para santrinya, misalnya dari tidak tahu menjadi tahu, dari sikap yang kurang baik menjadi lebih baik, dan dari tidak terampil menjadi terampil. Meningkatnya prestasi belajar di bidang ilmu tajwid yang diraih santri TPQ ArRisalah merupakan hasil dari ikhtiar inovasi dari penggunaan media konvensial ke media tajwid putar. 


\section{KESIMPULAN}

Pertama, dengan media tajwid putar di TPQ Ar-Risalah berlangsung secara aktif, interaktif dan menyenangkan sebagaimana cara yang dicontohkan oleh pencipta media itu. Media ini memperkuat penjelasan verbal dari guru serta contih-contoh yang ditulis di papan tulis. Hal ini mendorong daya ingat santri terhadap materi tajwid dan mampu membaca Alquran dengan baik. Kedua, penggunaan media tajwid putar meningkatkan antusiasme santri dalam belajar ilmu tajwid. Antusiasme santri lebih tinggi dibandingkan pada saat ustadz/ustadzah menggunakan media konvensional. Ketiga, prestasi tajwid santri di TPQ Ar-Risalah juga mengalami peningkatan. Hal ini dapat dilihat pada nilai ulangan dan tes (munaqosah) yang dimuat dalam buku rapor TPQ Ar-Risalah yang sudah mencapai kriteria ketuntasan minimal (KKM) yang telah ditetapkan oleh pihak lembaga.

Berdasarkan temuan ini, ke depan, perlu dilakukan studi komparatif dan research and development tentang implementasi pembelajaran ilmu tajwid dengan media tajwid putar baik di TPQ/TPA maupun di jenjang yang lebih tinggi seperti $\mathrm{SD} / \mathrm{MI}, \mathrm{SMP} / \mathrm{MTs}$, dan madrasah diniyah. Para pendidik dan praktisi pendidikan perlu menciptakan media pembelajaran hukum-hukum bacaan lainnya di dalam ilmu tajwid.

\section{DAFATAR PUSTAKA}

Arifin, Z. (2012). Evaluasi Pembelajaran. Bandung: Remaja Rosdakarya.

Askuri, I. (2018). Aplikasi Pengenalan dan
Pembelajaran Ilmu Tajwid Berbasis Android. Jurnal Mabasiswa Fakultas Teknik, $1(1), 6$.

Eiva, S., \& Putra, R. D. R. (2020). Based Tracking Sebagai Media Pembelajaran Ilmu Tajwid Pada Platform Android. SATIN-Sains dan Teknologi Informasi, 6(1), 45-52. DOI: https://doi.org/10.33372/stn.v6i1.599

Fajri, N. (2018). Implementasi Aplikasi Media Pembelajaran Belajar Tajwid Menggunakan Macromedia Flash 8 (Portable) pada Min 25 Aceb Besar (Undegraduate Thesis, UIN Ar-Raniry Banda Aceh).

Fathoni. (2018). Guru Madrasah Ini Cipatakan Alat Peraga Tajwid Putar dan Faraid Putar. NU Online: Beranda Islam Indonesia. Sumber: https://www.nu.or.id/post/read/99140 Lguru-madrasah-ini-ciptakan-alatperaga-tajwid-putar-dan-faraid-putar. Diakses: 2 Maret 2020.

Hamalik, O. (2014). Media Pendidikan. Bandung: Penerbit Alumni.

Kharisma, D., Irzal, M., \& Widyati, R. (2018). Rancang Bangun Aplikasi Makharijul Huruf dan Tajwid Berbasis Android Sebagai Penunjang Pembelajaran Tahsin Tilawah. J-KOMA: Jurnal Ilmu Komputer Dan Aplikasi, 2(1). DOI: https://doi.org/10.21009/jkoma.v2i1.6493

Lidinillah, M. (2014). Game Pengenalan Tajwid Berbasis Mobile dengan Metode Iterative Deepening $A^{*}$ untuk Penentuan Arah Gerak Musub (Undegraduate Thesis, Universitas Islam Negeri Maulana Malik Ibrahim).

Mildayanti, I., Arthana, I. K. R., Darmawiguna, I. G. M., \& Kom, S. (2016). Pengembangan Game Edukasi “Tajwid Al Qur'an” Berbasis Android. KARMAPATI (Kumpulan Artikel Mahasiswa Pendidikan Teknik. Informatika), 5(2), 249-258. DOI: http://dx.doi.org/10.23887/karmapati. v5i2.8302

Miles, M. B., \& Huberman, A. M. (1994). Qualitative Data Analysis: An Expanded Sourcebook. California: Sage. 
Mujib, F., \& Rahmawati, N. (2013). Metode Permainan-Permainan Edukatif dalam Belajar Bahasa Arab. Yogjakarta: Diva Press.

Rahmani, D. P. (2017). Implementasi Pembelajaran Tajwid dan Ketrampilan Membaca Al-Qur'an dalam Materi Qur'an Hadits Pada Siswa Kelas VII di MTs AlManar Bener Tengaran Tabun Ajaran 2016/2017 (Undegraduate Thesis, Fakultas Tarbiyah dan Ilmu Keguruan Institut Agama Islam Negeri Salatiga).

Ramdhanasari, D. (2013). Efektivitas Penggunaan Media Tajwid Putar terhadap Hasil Belajar dalam Pembelajaran pai: Studi Kuasi Eksperimen Pada Sub Pokok Bahasan Hukum Bacaan Nun Mati/Tanwin dan Mim Mati di SMP Negeri 3 Lembang Tabun Ajaran 2012/2013 (Undergraduate Thesis, Universitas Pendidikan Indonesia Bandung).

Rusyam, T. et.al. (1994). Pendekatan dalam Proses Belajar Mengajar. Bandung: Remaja Karya.

Rusydiyah, E. F. (2013). Media Pembelajaran: Implementasi untuk Anak di Madrasah Ibtidaiyah. Surabaya: IAIN Sunan Ampel Surabaya dan Islamic Development Bank.

Slameto. (2010). Belajar dan Faktor-faktor yang Mempengarubinya. Jakarta: Rineka Cipta.

Sudjana, N., \& Rivai, A. (2010). Media Pengajaran. Bandung: Sinar Baru Algensindo.

Sugiyono. (2014). Memahami Penelitian Kualitatif. Bandung: Alfabeta.

Sujiono, Y. N. (2013). Konsep Dasar Pendidikan Anak Usia Dini. Jakarta: Indeks.

Suryadi. (2007). Cara Efektif Memahami Perilaku Anak Usia Dini. Jakarta: EDSA Mahkota.

Syah, M. (2001). Psikologi Pendidikan dengan Pendekatan Baru. Bandung: Remaja Rosdakarya.

Witono. (2014). Penggunaan Media Ular Tangga untuk Meningkatkan Prestasi Tajwid Siswa di TPQ Mabadiul Ihsan Desa Karangdoro
Kecamatan Tengalsari Kabupaten Banyuwangi (Undegraduate Thesis, Fakultas Tarbiyah dan Ilmu Keguruan IAIN Jember).

Zain, N. A. (2017). Penggunaan Metode Drill pada Pelajaran Tajwid di Madrasah Diniyah Nurul Iman Pace Silo Jember (Undegraduate Thesis, Fakultas Tarbiyah dan Ilmu Keguruan Institut Agama Islam Negeri Jember).

Zulkarnain, F., Firdaos, R., \& Sada, H. J. (2019). Pengembangan Media Pembelajaran Qur'an Hadist dengan Magic Disc Tajwid. Al-Tadzkiyyah: Jurnal Pendidikan Islam, 10(2), 265-274. DOI: https://doi.org/10.24042/atipi.v10i2.5 $\underline{848}$ 